\title{
Effects of the aerial application of 1080 to control pest mammals on kea reproductive success
}

\author{
Joshua R. Kemp*, Corey C. Mosen, Graeme P. Elliott and Christine M. Hunter \\ Biodiversity Group, Department of Conservation, Private Bag 5, Nelson 7010, New Zealand \\ *Author for correspondence (Email: jkemp@doc.govt.nz)
}

Published online: 22 June 2018

\begin{abstract}
The kea (Nestor notabilis) and other New Zealand forest birds are threatened by predation by introduced mammals. Mammal control for biodiversity conservation in New Zealand commonly involves the aerial application of cereal-pellet baits containing sodium fluoroacetate ('Compound 1080'), but its effectiveness for kea conservation has not previously been assessed. This study examined the effects of aerial 1080 on the reproductive success of kea in a lowland rimu forest on the West Coast of New Zealand's South Island. We measured three parameters which collectively describe annual reproductive success (nesting frequency, nest survival and final chick count), within a Before-After-Control-Impact experiment. The Impact site was a 30000 ha area over which 1080 baits were aerially applied in the spring of a rimu (Dacrydium cupressinum) mast year (i.e. with heavy seedfall), with the After phase of the experiment lasting for two kea nesting seasons. The invasive mammals ship rat (Rattus rattus), brushtail possum (Trichosurus vulpecula) and stoat (Mustela erminea), which are potential predators of kea nests, were much less abundant in the Impact site after 1080 application, on the basis of standard indexing techniques. There was strong statistical support for an effect of aerial 1080 on kea nest survival. Aerial 1080 improved the odds of daily nest survival by a factor of 9.1 at the treatment site. Nest survival rates in the Control and Impact sites, before the application of 1080 , were $21 \%$ and $46.4 \%$, respectively. After the application of 1080 to the Impact site, nest survival increased to $84.8 \%$ in this site, whereas it declined to $12.2 \%$ in the untreated Control site. This substantial positive effect of aerial 1080 on kea nest survival is attributed to the effective control of mammalian nest predators, particularly the secondary poisoning of stoats.
\end{abstract}

\section{Introduction}

Many populations of New Zealand forest birds within large tracts of native forest are primarily limited by, and declining because of, predation by introduced mammals (Innes et al. 2010). Controlling such predators is consequently a central focus of conservation efforts in New Zealand (e.g. Elliott \& Kemp 2016). Positive effects of such management on survival and reproductive success have been measured for many species (O’Donnell et al. 1996; Innes et al. 1999, 2004; Moorhouse et al. 2003; Powlesland et al. 2003; Whitehead et al. 2008; O'Donnell \& Hoare 2012), but achieving good outcomes for birds is complicated by irruptive predator dynamics in New Zealand forests. These dynamics result from the dominance of massseeding (masting) plant species in New Zealand landscapes (Wardle 1984; Norton \& Kelly 1988). Predator species that limit forest bird populations include ship rats (Rattus rattus), stoats (Mustela erminea) and feral cats (Felis catus). Of these, irruptive population dynamics of rats and stoats in response to masting of rimu (Dacrydium cupressinum) and southern beech spp. (Nothofagus; sensu lato Hill et al. (2015)) are well described in the literature (King 1983; Murphy \& Dowding 1995; Murphy et al. 1998, 2008; Harper 2005). In snow tussock (Chionochloa spp.) grasslands, irruptive increases in stoat abundance may also potentially follow masting of snow tussocks, through increased availability of house mouse (Mus musculus) prey(Smith et al. 2007; Wilson\&Lee 2010). Studies of the population dynamics of feral cats in South Island forests are absent from the literature. The resource pulse associated with masting manifests early in a mast year (Fitzgerald et al.
2004) and can last until the following spring, during which time rodent populations (rat and/or mouse) increase exponentially (King 1983; Murphy 1992; Harper 2005; Murphy et al. 2008). High rodent density leads in turn to a stoat irruption during the post-mast year (the year after the mast year) (King 1983; Murphy \& Dowding 1995; Murphy et al. 2008). Feral cat populations, normally present only on the periphery of large forest tracts when rodents are scarce, may expand into these forests from adjacent pastoral lands and braided river beds so as to become noticeable during the post-mast year. Brushtail possum (Trichosurus vulpecula), an additional predator and/ or competitor associated with bird population limitation (Innes et al. 1999, 2004), potentially also responds to mast with higher productivity and survival (Sweetapple 2003), but intrinsic limitations on possum population growth prevent the high-magnitude irruptive spikes observed for rodents and stoats. New Zealand forest bird species vary in their susceptibility to these predators because of differences in bird size and behaviour (usually breeding behaviour), and the importance of birds in predator diets may change with rodent availability (Murphy et al. 2008). As a result, there is variation in the time within masting/irruption cycles at which predator impacts on native species are most acute. The timing of predator control, therefore, needs careful consideration and may vary among forest sites depending on threatened species assemblage, predator species assemblage and abundance between masts, and the masting propensity of the dominant vegetation. How to time predator control to benefit a broad range of forest flora and fauna, while prioritising the needs of threatened species (birds, bats, lizards and invertebrates) is the 
focus of current research by the Department of Conservation (DOC).

The kea (Nestor notabilis) is a threatened (Robertson et al. 2016) parrot endemic to the South Island, and may require management to assure its persistence on the mainland. Despite evidence that the kea is essentially a forest parrot (Rheindt et al. 2014), there is a popular misconception of a purely alpine (high-altitude, above treeline) distribution (e.g. Innes et al. 2010). This view arises because kea are cryptic in the forest and humans more often encounter them whilst tramping and skiing in the alpine zone. The kea population is difficult to manage because the species is spread very thinly across a large range (c. 4.5 million ha) (Jackson 1960; Robertson et al. 2007). If introduced predators are limiting kea numbers, predator control programmes will need to cover hundreds of thousands, or possibly millions, of hectares to conserve sufficient kea habitat to support a population with adequate genetic diversity.

Kea habitat is typically dominated by beech, rimu and snow tussocks, which means that mast seeding and predator irruptions are ecologically important for kea and will need to be considered when planning predator control for kea conservation. Kea lay eggs in small naturally-formed caves/ cavities, which are invariably on the ground and almost always below treeline. The vulnerability to predators associated with ground-nesting is exacerbated by the time needed to incubate eggs and raise nestlings, about four months (116 days) from egglaying to fledging. Nesting occurs in the spring (July-January). Unlike the other large New Zealand parrots the kākā (Nestor meridionalis) and the kākāpō (Strigops habroptilus), which breed only in response to mast, kea breeding pairs have been found to attempt nesting in several successive years, including years without mast (Jackson 1963). While some individual kea may not nest every year, attempted nesting by a portion of the population can be observed in most years, including the spring of the post-mast year during irruptive spikes in stoat, and potentially feral cat, numbers. Therefore, stoats and cats might limitkea populations. Rats, conversely, are unlikely to limitkea populations, based on studies of kākā (Beggs \& Wilson 1991; Wilson et al. 1998; Dilks et al. 2003; Moorhouse et al. 2003; Powlesland et al. 2003). However, rats may impact kea near the end of mast years, when rat populations peak while kea are nesting. The role of possum predation in kea population limitation is unknown, but is likely to be relatively constant across years due to the non-irruptive population dynamics of the possum.

Large-scale control of possums, rats, stoats and probably feral cats, can be done aerially in New Zealand forests using currently-approved methods (Innes et al. 1995; Murphy et al. 1999; Coleman et al. 2007; Nugent et al. 2011). Two poisons are currently approved for aerial use in New Zealand: Pindone and 1080 (sodium fluoroacetate), of which 1080 is by far the most widely used in kea habitat (Elliott \& Kemp 2016). Both effectively control possums and rats, but only 1080 has the potential to control carnivores such as stoats and feral cats through secondary poisoning (Murphy et al. 1999; Brown 2006). An aerial 1080 application generates a pulse of predator control, which is usually followed by one or more years without any control, during which predators repopulate by reinvasion from outside the controlled site and, potentially, breeding of survivors inside the site. Complementary ground control is sometimes done in small-scale sub-areas inside aerial treatment sites, but seldom on a scale relevant for kea population recovery. Prior to this study, there was no evidence that suppressing predators, either by aerial application of 1080 or by ground control methods, improves kea survival or productivity and thereby generates kea population growth. It is likely that benefits for kea from aerial 1080 vary with timing of application within mast-irruption cascades, and with the scale (geographic area) of bait application (larger areas may be repopulated more slowly).

Before 2006, aerial 1080 was used by DOC primarily as a possum control tool for the benefit of threatened plants and other possum-sensitive natural values. As a result, many treatment sites were $<10000$ ha and large-scale predator control was often absent in years of predator irruptions. For example, during 1999-2001, uncontrolled rat and stoat irruptions impacted heavily on relict bird and bat populations across South Island (Dilks et al. 2003; Pryde et al. 2005). These losses triggered research into aerial 1080 as a multi-pest control tool and the implementation of a flexible funding and planning process for delivering predator control operations. Aerial predator control can now be targeted spatially and temporally for the benefit of a broader range of natural values. In 2006, DOC began attempting to broaden the range of species benefitting from aerial 1080 in South Island forests by increasing the size of treatment sites and timing 1080 applications to coincide with the winter-spring of mast years (Elliott \& Suggate 2007; Elliott \& Kemp 2016). Within this programme, some operations are earlier (spring-early summer of the pre-mast year for kākā protection) or later (early summer of the post-mast year, usually due to logistical delays to a planned mast-year operation) (Elliott \& Kemp 2016).

Experimental evidence that native species benefit under this modern approach is necessary to ensure that species are, in fact, conserved and that the added complication in conservation planning is warranted. This study presents an experimental test of the hypothesis that large-scale aerial 1080 in the spring of a mast year improves the productivity of kea over two subsequent nesting seasons, during which predator abundance would normally be elevated. This study is particularly important for kea, as they are one of a few native species for which significant negative consequences of aerial 1080 have been detected (non-target poisoning) (Veltman \& Westbrooke 2011; JRK, unpubl. data). Quantifying the benefits of aerial 1080 for kea populations is essential to objectively determining the value of this management method for kea.

\section{Methods}

\section{Study area}

We studied kea productivity on the West Coast of the South Island, between Paringa and Whataroa, in old-growth native forests growing on glacial moraines between the Tasman Sea and the Southern Alps (Fig. 1). We worked primarily at altitudes $<500 \mathrm{~m}$ a.s.1., where the forest is dominated by tall emergent rimu over a canopy of kāmahi (Weinmannia racemosa) and southern rātā (Metrosideros umbellata). Initially, this study was designed with one beech forest replicate (Kahurangi) and one rimu forest replicate (Westland), but the physical difficulty of working in the mountains of Kahurangi National Park precluded efficient data collection and so that replicate was abandoned. The rimu-rātā-kāmahi forests typical of the successful replicate (this paper) comprise around $20 \%$ of the kea's breeding range. The other $80 \%$ of the kea's breeding range 


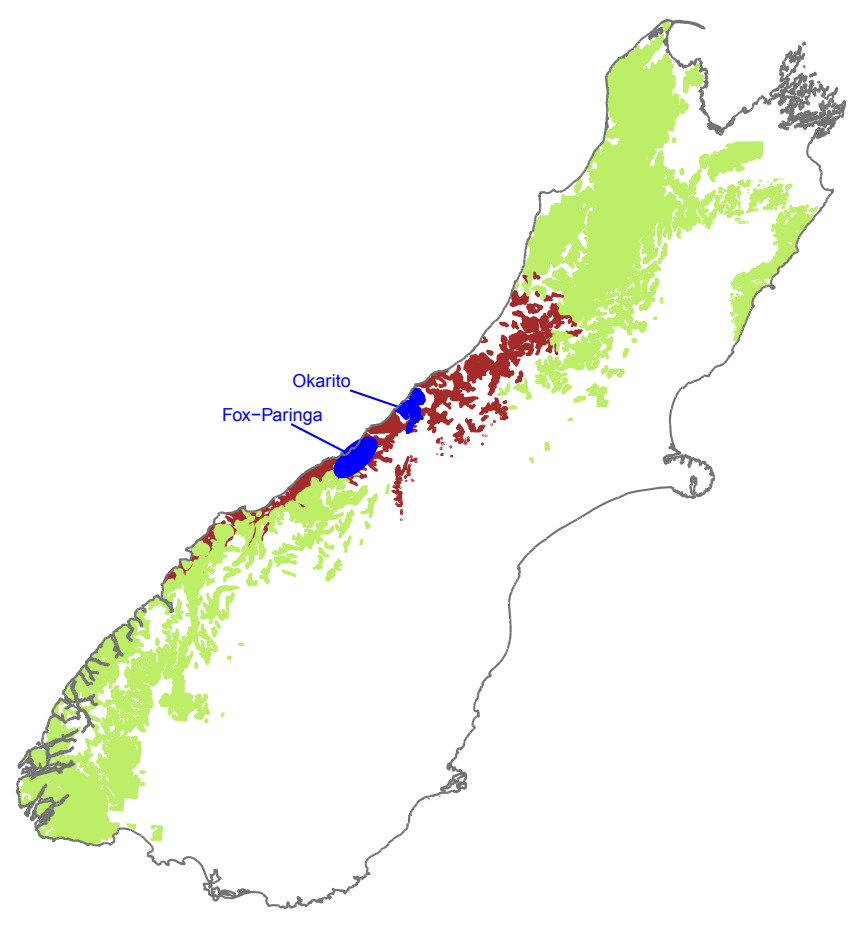

Figure 1. Map showing the location of the study sites (blue) within rimu-rātā-kāmahi forests (brown) on the West Coast of South Island. Beech forests also inhabited by kea are shown in green.

is predominantly upland beech forests and mixed beech-rimu forests.

We worked at two sites within the West Coast study area. The first, Okarito, was the Impact site of the Before-AfterControl-Impact experimental design. This site comprised the North and South Okarito forests, plus the adjacent mountain range to the east of these two forests. The Control site, referred to as Fox-Paringa, is bounded by the Fox and Paringa rivers, the Tasman Sea and the Southern alps, excluding the Copland Valley.

The Okarito site was the location of a c. 30000 ha aerial 1080 operation, proposed by the DOC and TBfree NZ in 2009 and delivered by TBfree NZ in the spring of 2011. The operation was triggered by an increase in relative abundance of rats (see Predator Indexing, below) in association with mast rimu seeding across South Island rimu forests in 2011. The increase in rat abundance in 2011 was a precondition for a potential stoat irruption in 2012. The Fox-Paringa site has never had a predator control programme of any sort. The Before phase of the experiment started in 2009 and the After phase commenced when 1080 was applied, on 4 September 2011. No other predator control was undertaken at the Okarito site during the study.

\section{Aerial 1080 application}

Pre-baiting (pre-feeding) with non-toxic cereal pellets was done on 18 August 2011, seventeen days before toxic baiting. Nontoxic pellets each weighed c. $6 \mathrm{~g}$ (16 mm diameter) and were sown at $1 \mathrm{~kg} \mathrm{ha}^{-1}$. Toxic pellets weighed c. $12 \mathrm{~g}(20 \mathrm{~mm})$ and were spread at $2 \mathrm{~kg} \mathrm{ha}^{-1}$. The toxic pellets contained $0.15 \%$ active ingredient by weight. All baits, toxic and non-toxic, contained cinnamon oil, which attracts target pests, repels some birds and masks the taste of impurities produced during the 1080 manufacturing process.

\section{Predator indexing}

We measured the relative abundance of stoats and possums at both sites over time because we considered these species to be potentially important predators of kea, based on studies of other birds including the kākā (Beggs \& Wilson 1991; Wilson et al. 1998; Moorhouse et al. 2003). We also measured the relative abundance of rodents because of their importance as drivers of stoat abundance and vectors of poison to stoats (Brown et al. 1998a; Murphy et al. 1999; Alterio \& Moller 2000), and also because ship rats might prey directly on kea eggs and nestlings. Feral cats were not monitored because of the lack of an established indexing method. However, automatic cameras placed at kea nests during the study (see kea reproductive success section, below) detected stoats, rats and possums, but not cats, indicating that cats were relatively unimportant to our study kea population. Furthermore, cats and cat field sign were not observed in the field at any time during the study.

We measured stoat and rodent relative abundance with quarterly 'footprint tracking tunnel' surveys, from which we calculated a Footprint Tracking Index (FTI) (Gillies \& Williams 2013). Tracking tunnel surveys were conducted along semipermanent $450 \mathrm{~m}$ long transects, along which were installed ten black plastic tunnels at $50 \mathrm{~m}$ intervals. Transects were spread widely within the forest, separated from each other by $1 \mathrm{~km}$ or more. Fifteen such transects were used in South Okarito Forest and twelve were used in the Fox-Paringa site. Rodent surveys utilised all ten tunnels on each transect, baited with peanut butter and set for one night. Stoat surveys utilised alternate tunnels, baited with fresh rabbit meat and set for three nights.

We measured the relative abundance of possums on the basis of captures in leg-hold traps, from which we calculated a Residual Trap Catch Index (RTCI) (NPCA 2011). Possum survey transects were temporary, and comprised twenty Victor 1.5 " soft-jaw traps on raised sets, at $20 \mathrm{~m}$ spacings along transects of $180 \mathrm{~m}$ in length. At Okarito a pre-1080 survey in December 2009 used twelve transects run for two consecutive nights (240 trap nights). A post-1080 RTCI in Jan-April 2012 used twenty transects run for two consecutive nights (400 trap nights). At Fox-Paringa, a February 2010 survey used six transects (120 trap nights).

\section{Kea capture and marking}

Kea were located by walking through the landscape along prominent ridges and spurs, listening for kea calls and playing recorded calls. Once located, kea were induced to approach our traps (snares and handheld net guns) by playing additional calls and by deploying stuffed kea decoys. Captured kea were radio-tagged with c. $24 \mathrm{~g}$ VHF transmitters using a backpack harness made of $2 \mathrm{~mm}$ braided nylon (Karl \& Clout 1987). The harnesses incorporated a biodegradable link to facilitate shedding of the transmitter after 2 to 3 years. Battery life was 24 to 36 months.

Captured kea were also fitted with a numbered, stainless steel leg band. Prior to 2011, powder-coated coloured stainless steel leg bands were fitted to enable visual identification of individuals from a distance using binoculars. In 2011, these were superseded by dual-colour plastic wraparound Interrex ${ }^{\circledR}$ leg bands engraved with alpha-numeric symbols for visual identification at a distance, coupled with a single stainless steel numbered band.

\section{Kea reproductive success}

Kea nesting attempts were detected by following radio-tagged 
adults of both sexes and by visual assessment of nesting cavities that we had found in previous years. Visual assessments involved peering into the nest cavity with a torch in hand, sometimes assisted by a mirror on a pole or a fibre-optic viewing camera and portable viewing screen. Kea are known to re-use nest cavities, and when this happened we were able to capture/recaptureadultfemalekea forradio-tagdeployment.

The effect of aerial 1080 was assessed on three components of kea reproductive success: nesting frequency, nest survival and final chick count. Nesting frequency was defined as the proportion of adult females that lay eggs each year. A successful nest was defined as the production of at least one fledged offspring from a nest attempt (Rotella et al. 2004). Final chick count was the number of offspring that fledged from successful nests. Other parameters commonly measured in studies of bird reproductive success such clutch size and hatching success could not be quantified. Nonetheless, the three parameters we did measure enable annual reproductive success (female offspring produced per female per year) to be calculated, provided that adult female survival rates are known.

We estimated nesting frequency by radio-tracking radiotagged adult females at 2-3 weekly intervals, from July to December in 2009-2012, in search of evidence of attempted nesting. A female was scored as having attempted nesting only when found with eggs, eggshells, or nestlings. To obtain an unbiased estimate of nesting frequency, only females that were discovered and radio-tagged prior to the start of a breeding season were used. Females discovered because they were nesting (for example, in a nest cavity that we had previously identified) were not included in the analysis of nesting frequency.

Nest survival was monitored by repeated observations of nest attempts at intervals of approximately 3 weeks. Predator sign at kea nests can be cryptic (Brown et al. 1998b), and kea may remove dead eggs and chicks (Jackson 1963), so that nothing is found at a failed nest attempt but an empty nest cavity. Consequently, distinguishing nest failure from early fledging becomes increasingly difficult as nestlings approach fledging age. Automatic cameras (Scoutguard SG550 and LTL Acorn) mounted outside and, in a few cases, inside nest cavities, were introduced partway through the study; these helped distinguish between successful fledging and late-stage failure, as did radio-tagging fully-grown nestlings. At nests where these techniques were not used, monitoring histories were restricted to the first 100 days to prevent misclassifying nests as 'failed' when in fact chicks had fledged early, and vice versa. We estimated the date of laying of the first egg by using counts of eggs in successive observations and/or by comparing the size and plumage characteristics of nestlings to a reference collection of photographs of known-age nestlings. Final chick count was determined for successful nests by counting the number of chicks present on the day of fledging. To assist with interpretation of the nest survival results, we plotted the egglaying dates of the nesting attempts we monitored as kernel densities (smoothed histograms) with respect to site and time. We used function geom_density in the ggplot2 package for R (Wickham 2009).

\section{Statistical analysis}

We used separate statistical analyses for each component of reproductive success (nesting frequency, nest survival and final chick count). For each component, we compiled a priori a list of alternative competing models of factors affecting the response variable. The model sets reflected the Before-AfterControl-Impact study design, comprising a Constant (Null) model with no covariates, a site-only model (Okarito versus Fox-Paringa), a time-only model (Before 1080 versus After 1080), a model with both site and time, and a model with site, time and an interaction between site and time. The model with the interaction is of key interest because it includes the aerial 1080 effect while controlling for site and time effects.

All analyses were conducted within the program R (R Core Team 2016). Nesting frequency was analysed using logistic regression in the lme 4 package (Bates et al.2015). Nest survival was analysed using the daily survival method (Mayfield 1961), following Dinsmore et al. (2002), implemented in program MARK (White \& Burnham 1999) via the package RMark (Laake 2013). The Dinsmore et al. (2002) approach avoids bias arising if nests are found at various ages, as they were in our study, and enables modelling of time-varying covariates. This method produces estimates of daily nest survival which we transformed to overall nest survival (hereafter referred to simply as 'nest survival') by raising daily nest survival estimates to the power of 116, the approximate number of days required to incubate an egg and raise a nestling to fledging age. Final chick count was analysed using zero-truncated Poisson regression in the VGAM package (Yee 2010).

We ranked competing models on the basis of Akaike's Information Criterion (AIC; Akaike 1973) corrected for small sample sizes (AICc) and considered models within two AIC units of the top ranked model as competitive (Burnham \& Anderson 1998). Representation within competitive models was considered evidence that an explanatory variable was associated with the response variable in a non-random way, assuming independence of sampling units and binomial errors, or, in the case of final nestling count, Poisson errors. We use the odds ratio to express the magnitude of the effect for supported covariates. For aerial 1080 treatment we calculate this as:

$$
O R_{1080}=\left(\frac{e^{\beta_{i}+\beta_{s}+\beta_{t}+\beta_{s: t}}}{e^{\beta_{i}+\beta_{s}}}\right)
$$

where $\beta_{i}, \beta_{s}, \beta_{t}, \beta_{s: t}$ are the model coefficients for the intercept, site, time and the site:time interaction term, respectively.

Model validation tools for Bernoulli trials (nest survival and nesting frequency) involving categorical covariates with only two levels, such as site and time in our study, are not available.

\section{Results}

\section{Predator abundance}

Footprint tracking tunnel surveys showed increases in the relative abundance of rats at both sites during the 2011 mast year (Fig. 2). However, the first post-1080 tracking tunnel survey, conducted two weeks after the 1080 drop, recorded less than $1 \%$ tracking for both rats and stoats at Okarito. Conversely, rats and stoats continued to increase at Fox-Paringa, with rats peaking at $>80 \%$ tracking during summer-autumn 2011-2012. A natural post-irruption rat decline during winter 2012 brought this rat tracking index down to pre-irruption levels of $10-30 \%$. In contrast, rat abundance at Okarito increased during 2012. Mouse tracking increased temporarily at Okarito during the period of suppressed rat tracking following the 1080 application. Stoat FTI remained near zero at Okarito for the kea nesting seasons in 2011 and 2012. Conversely, at 


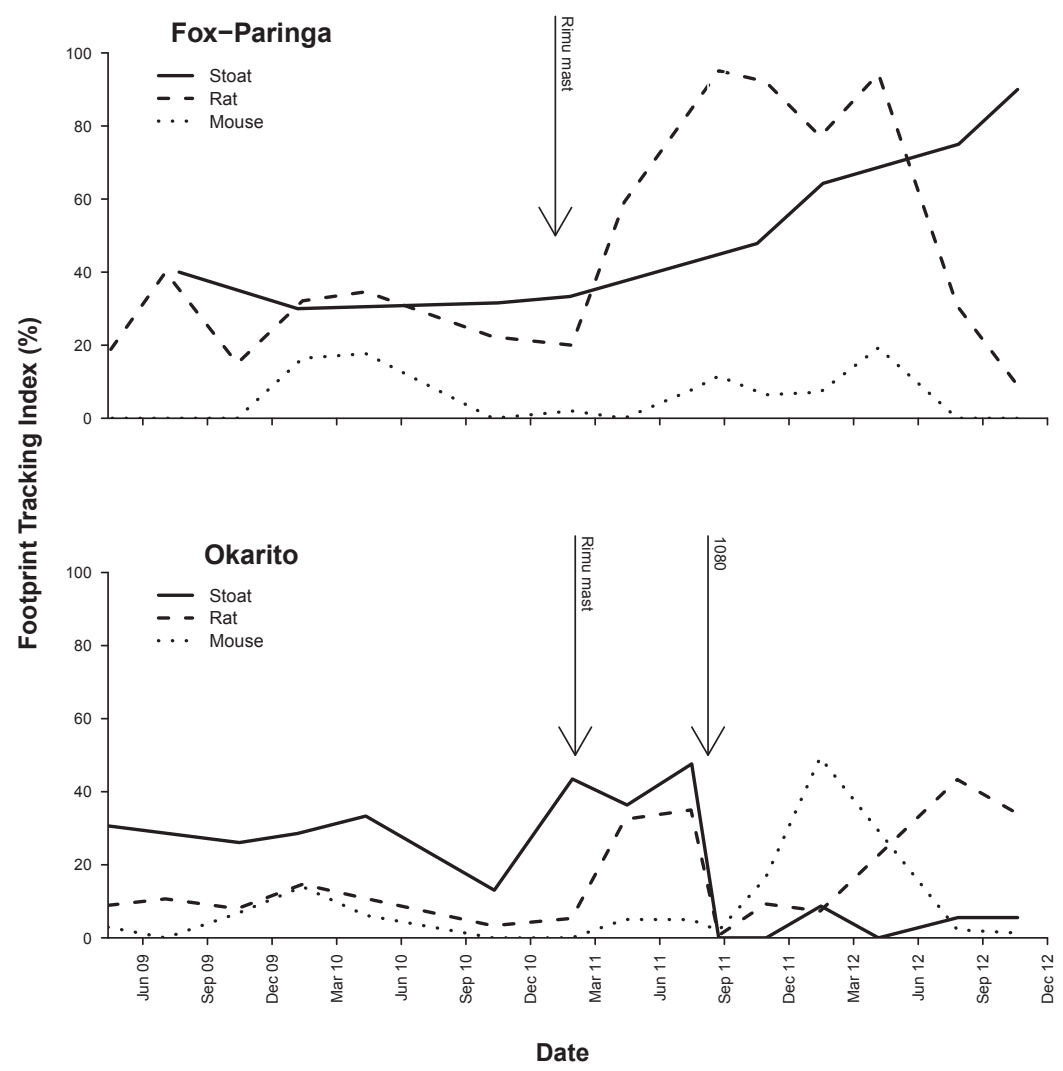

Figure 2. Relative abundance of rats, mice and stoats at the untreated Control site (Fox-Paringa) and in the 1080-treated Impact site (Okarito) from winter 2009 to summer 2012, measured using tracking tunnels. Rodent tracking rates are mean \% of tunnels tracked per transect. Stoat tracking rates are percentage of transects that detected stoats. The 'rimu mast' arrow indicates the peak of seed availability and the ' 1080 ' arrow indicates the timing of the aerial 1080 application.

Fox-Paringa, stoats were relatively abundant during 2012. The difference in rat and stoat tracking indices between the two sites suggests that a high proportion of both rats and stoats were killed at Okarito by the 1080 treatment.

Possum Residual Trap Catch Index (RTCI) measures during the Before phase of the experiment were 5.9\% and $6.3 \%$ at Fox-Paringa and Okarito, respectively. Possum RTCI during the After phase was measured only at Okarito, where a reduction to $0.5 \%$ was recorded.

\section{Nesting seasons}

The onset of nesting was consistent across the study area and among seasons $(n=47$ nesting attempts). Egg laying commenced in early July each year (Fig. 3). During the Before phase of the experiment, egg laying proceeded at an even rate from July-October at both sites. However, during the After phase, an early, sharp peak in egg laying was observed at Okarito in association with high nest survival (see nest survival section, below). Conversely, egg-laying atFox-Paringapeaked later in the season in association with high rates of egg loss and successive failed nesting attempts during the 2012 stoat irruption.

\section{Nesting frequency}

Anesting frequency dataset of 34 adult-female-radio-trackingyears was accumulated from 17 adult females at both sites combined (Fig. 4). Of the 17 females, three were tracked for one nesting season, 11 were tracked for two seasons and three were tracked for three seasons. Nesting attempts were detected in 20 of the 34 female-years.

None of the modelled covariates were useful predictors of nesting frequency (Table 1). The best model was the Constant model, in which all records (i.e. female-years) were considered

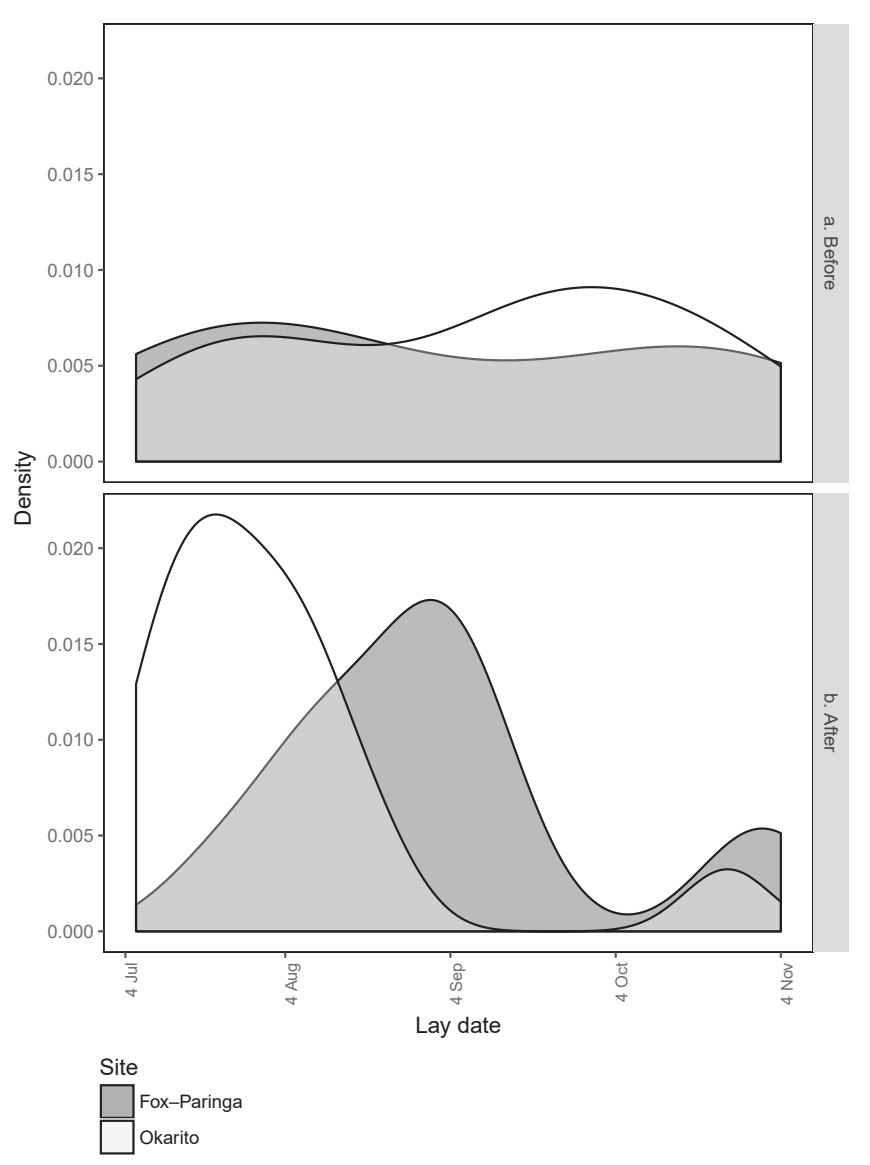

Figure 3. Kernel densities (smoothed histograms) for the timing of egg laying with respect to site and time in Westland, based on the 47 nest attempts detected during the study. 

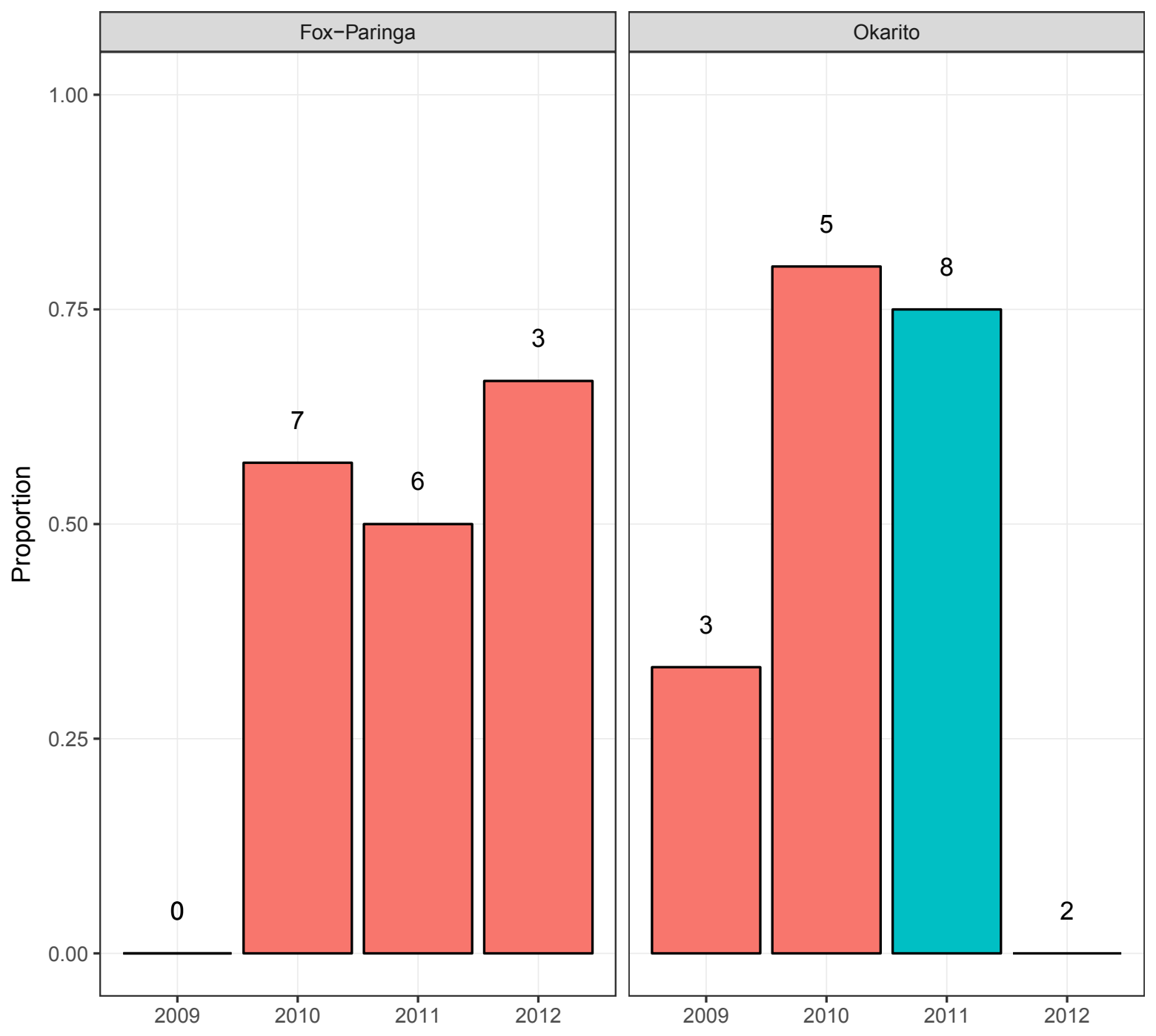

BACl group $\square$ Control Before \& After, Impact Before $\square$ Impact After

Figure 4. The proportion of adult females that attempted nesting. Blue bars represent females in the Impact site After aerial 1080 control; orange bars represent females in the Control site and/or Before aerial 1080 application. Numbers above bars are the number of females monitored for nest attempts. Note that numbers of nests found from the nesting frequency sample differs from the numbers of nests monitored for nest survival because additional nests, found by visiting old nest cavities, tracking radio-tagged males, or tracking females previously located for radio-tagging because they were nesting, were included in the nest survival analysis (see methods).

Table 1. Model ranking and weighting, by AICc, for competing models of factors affecting nesting frequency (the annual probability that an adult female kea attempts a nest/lays eggs). Site $=$ Control/Impact, Time $=$ Before $/$ After, Site:Time = interaction between Site and Time (the effect of 1080 application). $\mathrm{k}=$ Number of parameters in model.

\begin{tabular}{lccc}
\hline Model & $\mathbf{k}$ & $\begin{array}{c}\text { Delta } \\
\text { AICc }\end{array}$ & $\begin{array}{c}\text { Model } \\
\text { Weight }\end{array}$ \\
\hline Constant & 1 & 0 & 0.558 \\
Site & 2 & 2.179 & 0.188 \\
Time & 2 & 2.247 & 0.182 \\
Site + Time & 3 & 4.577 & 0.057 \\
Site + Time + Site:Time & 4 & 7.156 & 0.016 \\
\hline
\end{tabular}

Table 2. Numbers of kea nests that failed, total nest exposure days accumulated and number of kea nests found (in brackets) in our West Coast study area from 2009-2012. Fox - Paringa $=$ Control site, Okarito $=$ Impact site treated with 1080 in September 2011. For example, in 2010 at Okarito, four nests failed within a total of 536 nest-exposure days accumulated from seven nesting attempts. At FoxParinga, the same number of nests failed within 353 nestexposure days accumulated from seven nesting attempts.

\begin{tabular}{lcccc}
\hline Site & $\mathbf{2 0 0 9}$ & $\mathbf{2 0 1 0}$ & $\mathbf{2 0 1 1}$ & $\mathbf{2 0 1 2}$ \\
\hline Okarito & $3 ; 302(5)$ & $4 ; 536(7)$ & $0 ; 791(9)$ & $1 ; 577(6)$ \\
Fox-Paringa & $0 ; 0(0)$ & $4 ; 353(7)$ & $3 ; 377(6)$ & $7 ; 204(7)$ \\
\hline
\end{tabular}


equal. Nesting frequency, as estimated by the Constant model, was $0.59(95 \% \mathrm{CI}=0.42-0.75)$.

\section{Nest survival}

A total of 3140 days of nest survival data were collected from 47 nesting attempts, 20 at Fox-Paringa and 27 at Okarito, of which 22 failed at both sites combined (Table 2).

There was strong statistical support for a positive effect of the aerial 1080 application on nest survival, as indicated by the clear superiority of the model containing the site:time interaction, which tested the 1080 effect (Table 3). Aerial 1080 improved the odds of daily nest survival at Okarito by a factor of 9.1, during the two-year post-1080 period (95\% $\mathrm{CI}=0.4-190.3)$.

Model-averaged (across all models) nest survival prior to the application of 1080 to the Okarito site was $46.4 \%$ (95\% CI $=16-72.5 \%)$ at Okarito and 21\% (2.6-51.4\%) at Fox-Paringa (Fig. 5).After the 1080 treatment at Okarito, nest survival there increased to $84.8 \%(28.2-97.9 \%)$, whereas over the same twoyear period it declined to $12.2 \%(1.6-34.4 \%)$ at Fox-Paringa.

\section{Final chick count}

The number of offspring fledged from the 25 successful nests was two in most $(56 \%)$ cases, followed by one $(32 \%)$, three $(8 \%)$ and a single case of four offspring (4\%) (Fig. 6). Final chick count was not affected by the aerial 1080 operation (Table 4). The mean number of offspring fledged from successful nests was $1.84(\mathrm{SD}=0.75)$.

\section{$\triangle$ Control (Fox-Paringa) Before \& After \\ Impact (Okarito) Before \\ Impact (Okarito) After}

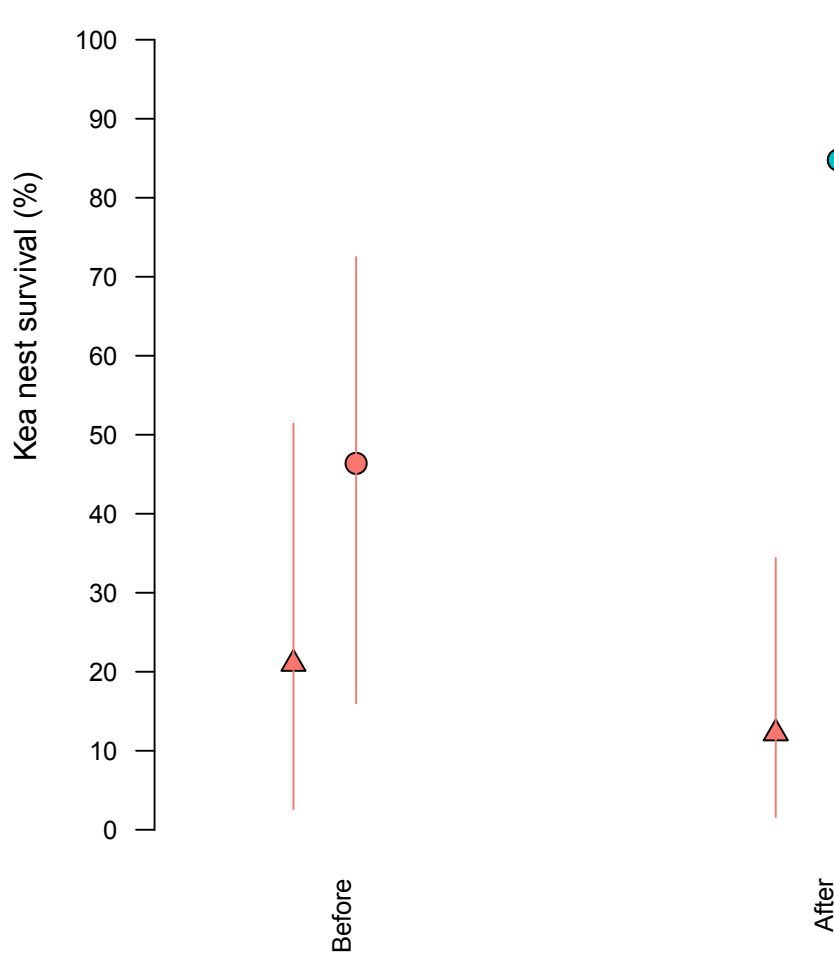

Figure 5. Model-averaged kea nest survival rates in the control site (Fox-Paringa) and the Impact site (Okarito) Before and After aerial 1080 application at Okarito in spring 2011. Error bars are $95 \%$ confidence intervals.
Table 3. Model ranking and weighting, by AICc, for competing models of factors affecting kea nest survival. Site $=$ Control/Impact, Time $=$ Before/After, Site:Time $=$ interaction between Site and Time (the effect of 1080 application). $\mathrm{k}=$ Number of parameters in model.

\begin{tabular}{lccc}
\hline Model & k & $\begin{array}{c}\text { Delta } \\
\text { AICc }\end{array}$ & $\begin{array}{c}\text { Model } \\
\text { Weight }\end{array}$ \\
\hline Site + Time + Site:Time & 4 & 0 & 0.773 \\
Site & 2 & 3.34 & 0.146 \\
Site + Time & 3 & 4.556 & 0.079 \\
Constant & 1 & 12.82 & 0.001 \\
Time & 2 & 13.9 & 0.001 \\
\hline
\end{tabular}

Table 4. Model ranking and weighting, by AICc, for competing models of factors affecting the final chick count at successful nests. Site $=$ Control/Impact, Time $=$ Before $/$ After, Site:Time = interaction between Site and Time (the effect of 1080 application). $\mathrm{k}=$ Number of parameters in model.

\begin{tabular}{lccc}
\hline Model & $\mathbf{k}$ & $\begin{array}{c}\text { Delta } \\
\text { AICc }\end{array}$ & $\begin{array}{c}\text { Model } \\
\text { Weight }\end{array}$ \\
\hline Constant & 1 & 0 & 0.5229 \\
Time & 2 & 1.786 & 0.2141 \\
Site & 2 & 2.116 & 0.1815 \\
Site+Time & 3 & 4.259 & 0.06218 \\
Site + Time + Site:Time & 4 & 6.596 & 0.01933 \\
\hline
\end{tabular}

\section{Discussion}

This study provides evidence that aerial 1080 improves the reproductive success of kea by increasing the proportion of nesting attempts that result in fledged chicks (nest survival). Only one of fifteen nesting attempts failed at Okarito during the two breeding seasons after 1080 treatment, whereas ten out of thirteen nests failed in the untreated Fox-Paringa site, including seven failures out of seven nests during the stoat irruption year of 2012. These results are consistent with differences in predator abundance (principally stoats) between the sites, which are attributable to the application of aerial 1080 at Okarito (Murphy et al. 1999). This finding is, in turn, consistent with studies of the kea's sympatric congener, the $k a \bar{k} \bar{a}$, for which nest survival is very low without pest-mammal control and increases markedly after removal of stoats and possums (Moorhouse et al. 2003). Our result contrasts with one study of kākā nest survival (Greene et al. 2004) in which 1080 application over a comparatively small 10000 ha site of North Island podocarp forest that lacked significant natural barriers to reinvasion improved kākā nest survival for only a single nesting season. We attribute the more prolonged period of stoat suppression and associated improvement in kea nest survival at Okarito to the larger area (30 $000 \mathrm{ha}$ ) of this site and its extensive natural barriers to reinvasion by predators (ocean to the west, permanent snow and ice to the east).

Our analysis showing that final chick counts at successful nests were not significantly altered by predator control can be explained if predators, when raiding a kea nest, typically 

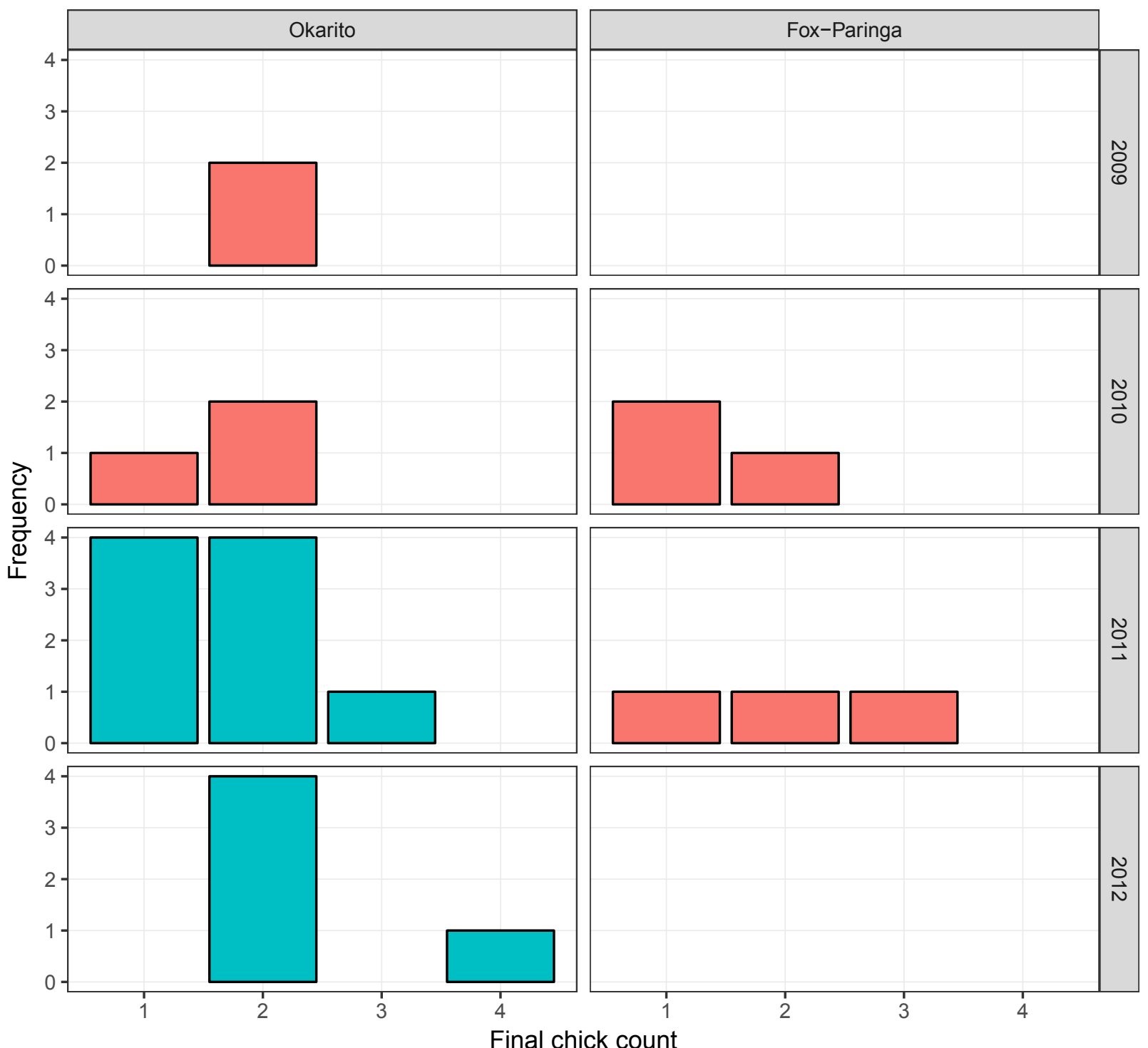

BACl group $\square$ Control Before \& After, Impact Before $\square$ Impact After

Figure 6. The frequency with which different numbers of kea chicks fledged from successful nests ( $\mathrm{n}=25$ fledged nests). Blue bars indicate final chick counts in the Impact site After aerial 1080 control.

kill all eggs and/or nestlings, rather than taking only some eggs or nestlings. If so, predator control should not influence the mean number of offspring that come from a successful nest, as we found. The mean number of offspring fledged from successful nests in our study (1.84) was very similar to the 1.6 found by Jackson (1963) in unmanaged upland beech forest at Arthur's Pass in the 1950s.

The factors that influence the decision of kea to nest in any given year (nesting frequency) were not identified by this study. For many parrots, nutritional considerations are key determinants of nesting (e.g. Moorhouse 1991). However, we saw no obvious signs of food shortage, nor of disease, such as low body mass, parasites and/or degraded appearance, to suggest that food supply limited nesting frequency. Alternative explanations for the observed absence of nesting in $41 \%$ of adult-female monitoring years are that some of our study birds were sub-adults or newly matured females with an inherently low probability of nesting, and that some nests failed before they were detected. The changes in egg-laying patterns we recorded after aerial 1080 application and during a stoat irruption suggest that we did miss nesting attempts due to rapid and early failure, and hence we have under-estimated nesting frequency.

Our result of a positive effect of aerial 1080 application on kea reproductive success should be directly applicable to other large-scale aerial 1080 operations in South Island forests with similarpredatorassemblages and masting dynamics. Our lowland rimu forested study area in Westland is characteristic of about $20 \%$ of the current kea breeding range. The remaining $80 \%$ is comprised mostly of upland beech forests and mixed beech-rimu forests, both of which also exhibit mast seeding dynamics. Fortunately, comparison of our predator indexing 
results from Westland with those from upland beech forests (see Elliott \& Kemp 2016) shows that predator dynamics are very similar between the two. The low-moderate rodent abundance recorded at Fox-Paringa during the inter-mast period (before 2011) followed by the rapid increase during the 2011 mastyear, then the population crash in 2012, is very similar to temporal patterns of rodent abundance recorded in upland beech forests throughout New Zealand(Elliott \& Kemp 2016). A potentially important difference between rimu and beech forests is that rodent irruptions in beech can be dominated by mice as opposed to rats. Fisher et al. (2009) found that mice can 'detect 1080' and predicted that this would prevent mice consuming a lethal quantity of poison bait resulting in poor mouse kills. Consequently, poor stoat kills by secondary poisoning might be predicted in beech forests. However, aerial 1080 can significantly reduce mouse abundance (unpublished data, Department of Conservation), implying that the high level of stoat mortality through secondary poisoning at the rat-dominated Okarito site (and see Murphy et al. 1999) could also occur in a mouse-dominated rodent context.

The predator indexing results at Okarito indicate that aerial 1080 can have medium-term (2-3+ years) consequences for small-mammal populations in New Zealand lowland forests (mice, rats, possums, stoats). Consistent with the results of other studies in lowland forests (but not upland ones) (Tompkins \& Veltman 2006; Sweetapple \& Nugent 2007; Ruscoe et al. 2011), the short-medium term (12-18 months) suppression of rats, possums and stoats after aerial 1080 at Okarito was followed by a short term (3-6 months) spike in mouse abundance and then a medium-term (2-3 years) spike in rat density.Amedium-term increase in rat carrying-capacity could be attributed to the combined absence of predation by stoats on rats and increased food availability due to suppression of rats and possums. While this study demonstrated clear benefits of aerial 1080 for kea reproductive success over two years, the effect of this medium-term rat increase on smaller rat-sensitive native inhabitants of lowland 1080-treated forests (e.g. Ruscoe et al. 2013) requires attention.

We have shown that the benefits of aerial 1080 application to native species can be broadened to include birds such as the kea, by attention to scale and timing of operations with respect to mast. Continued attention to masting and scale by designers of DOC's 1080 programme is warranted despite the consequent increased complexity of conservation planning processes. The benefits of aerial 1080 to kea reproductive success probably extend to other annually breeding large native bird species such as whio (Hymenolaimus malacorhynchos), takahe (Porphyrio hochstetteri) and kiwi (Apteryx spp.), which are primarily threatened by predation by stoats where other larger carnivores are absent (McLennan et al. 1996; Whitehead et al. 2008; Hegg et al. 2012). However, aerial 1080 with the timing used in this study would not have benefitted kākā because 1080 was applied about 6 months after the end of the kākā nesting season, which is in the summer of mast seed formation, in this case summer 2010/11. Further measurement of benefits of aerial 1080 to a range of native species of various body size and predator vulnerability is required so that the national 1080 programme can be tailored to benefit whole forest communities.

In summary, our results indicate that large-scale aerial 1080 operations can significantly improve kea reproductive success by reducing the abundance of predators, and particularly by suppressing stoat irruptions. Aerial 1080 is, therefore, a valuable, if not essential, tool for conservation of kea, provided that its benefits are sufficient to offset any mortality from the ingestion of 1080 by kea (JRK, unpubl. data).

\section{Acknowledgements}

ThisresearchwascarriedoutbytheDepartmentofConservation with co-funding from TBfree NZ, a subsidiary of OSPRI New Zealand. Radio tagging, banding and nest monitoring of kea was conducted in accordance with Department of Conservation Animal Ethics Guidelines. For assistance with the massive field effort that went into this study we thank Francesca Cunninghame, Brent Barrett, Joseph Fraser, Troy Makan, Jacinda Amey, Paul van Klink, Dan Palmer, Lucy Rossiter, Vanessa Smith and Liam Bolitho. We thank the staff of the (then) Franz Josef/Waiau and Fox Glacier/Weheka Area Offices of the Department of Conservation for facilitating our field work, especially Jo MacPherson and Jim Livingstone. Comments from Susan Timmins, Ximena Nelson, Alex Taylor and Laura Young greatly improved the manuscript, for which we are grateful. We also thank Amy Whitehead, Ron Moorhouse and Deb Wilson (NZJE reviewers and associate editor) for their support for, and valuable input to, the manuscript.

\section{References}

Akaike H 1973. Information theory and an extension of the maximum likelihood principle. In Petran B and Csaki $\mathrm{F}$ eds. International symposium on information theory. Budapest, Akademiai Kiado. Pp. 267-281.

Alterio N 2000. Controlling small mammal predators using sodium monofluoroacetate (1080) in bait stations along forestry roads in a New Zealand beech forest. New Zealand Journal of Ecology 24: 3-9.

Alterio N, Moller H 2000. Secondary poisoning of stoats (Mustela erminea) in a South Island podocarp forest, New Zealand: implications for conservation. Wildlife Research 27: 501-508.

Bates D, Maechler M, Bolker B, Walker S 2015. Fitting Linear Mixed-Effects Models Using lme4. Journal of Statistical Software 67: 1-48.

Beggs J, Wilson P 1991. The kaka Nestor meridionalis, a New Zealand parrot endangered by introduced wasps and mammals. Biological Conservation 56: 23-38.

Brown KP, Alterio N, Moller H 1998a. Secondary poisoning of stoats (Mustela erminea) at low mouse (Mus musculus) abundance in a New Zealand Nothofagus forest. Wildlife Research 25: 419-426.

Brown KP, Moller H, Innes J, Jansen P 1998b. Identifying predators at nests of small birds in a New Zealand forest. Ibis 140: 274-279.

Burnham KP, Anderson DR 2002. Model selection and multimodel inference: a practical information-theoretic approach. 2nd edn. New York, Springer-Verlag. 488 p.

Coleman JD, Fraser KW, Nugent G 2007. Costs and benefits of pre-feeding for possum control. New Zealand Journal of Zoology 34: 185-193.

Dilks PJ, Willans M, Pryde M, Fraser I 2003. Large scale stoat control to protect mohua (Mohoua ochrocephala) and kaka (Nestor meridionalis) in the Eglinton Valley, Fiordland, New Zealand. New Zealand Journal of Ecology 27: 1-9.

Dinsmore SJ, White GC, Fritz LK 2002. Advanced techniques for modeling avian nest survival. Ecology 8: 3476-3488. 
Elliott G, Kemp J 2016. Large-scale pest control in New Zealand beech forests. Ecological Management \& Restoration 17: 200-209.

ElliottGP, Suggate R 2007. Operation Ark: Three year progress report. Christchurch, Department of Conservation, New Zealand. 86 p.

Fisher P, Airey A, Brown S 2009. Effect of pre-feeding and sodium fluoroacetate (1080) concentration on bait acceptance by house mice. Wildlife Research 36: 627-636.

Fitzgerald BM, Efford MG, Karl BJ 2004. Breeding of house mice and the mast seeding of southern beeches in the Orongorongo Valley, New Zealand. New Zealand Journal of Zoology 31: 167-184.

Gillies C, Williams D 2013. DOC tracking tunnel guide v2.5.2: Using tracking tunnels to monitor rodents and mustelids. Hamilton, Department of Conservation. 14 p.

Greene TC, Powlesland RG, Dilks PJ, Moran L 2004. Research summary and options for conservation of kaka (Nestor meridionalis). DOC Science Internal Series 178. Wellington, Department of Conservation. 26 p.

Harper G 2005. Heavy rimu (Dacrydium cupressium) mast seeding and rat (Rattus spp.) population eruptions on Stewart Island/Rakiura. New Zealand Journal of Zoology 32: $155-162$.

Hegg D, Greaves G, Maxwell JM, MacKenzie DI, Jamieson I 2012. Demography of takahe (Porphyrio hochstetteri) in Fiordland: Environmental factors and management affect survival and breeding success. New Zealand Journal of Ecology 36: 75-89.

Hill RS, Jordan GJ, MacPhail MK 2015. Why we should retain Nothofagus sensu lato. Australian Systematic Botany 28: 190-193.

Innes J, Warburton B, Williams D, Speed H, Bradfield P 1995. Large-scale poisoning of ship rats (Rattus rattus) in indigenous forests of the North Island, New Zealand. New Zealand Journal of Ecology 19: 5-17.

Innes J, Hay R, Flux I, Bradfield P, Speed H, Jansen P 1999. Successful recovery of North Island kokako (Callaeas cinerea wilsoni) populations, by adaptive management. Biological Conservation 87: 201-214.

Innes J, Barker G, Prime K, Spurr EB 2004. Responses of kukupa (Hemiphaga novaeseelandiae) and other birds to mammal pest control at Motatau, Northland. New Zealand Journal of Ecology 28: 73-81.

Innes J, Kelly D, Overton JM, Gillies CA 2010. Predation and other factors currently limiting New Zealand forest birds. New Zealand Journal of Ecology 34: 86-114.

Jackson JR 1960. Keas at Arthurs Pass. Notornis 9: 39-58.

Jackson J 1963. The nesting of Keas. Notornis 10: 319-326.

Karl BJ, Clout MN 1987. An improved radio transmitter harness with a weak link to prevent snagging. Journal of Field Ornithology 58: 73-77.

King CM 1983. The relationships between beech (Nothofagus spp.) seedfall and populations of mice (Mus musculus), and the demography and dietary responses of stoats (Mustela erminea), in three New Zealand forests. Journal of Animal Ecology 52: 141-166.

Laake J 2013. RMark: An R interface for analysis of capturerecapture data with MARK. AFSC Processed Report 2013-01, Seattle, Alaska Fisheries Science Centre. 25 p.

Mayfield H 1961. Nesting success calculated from exposure. Wilson Bulletin 73: 255-261.

McLennan JA, Potter MA, Robertson HA, Wake GC, Reid J, Lyall J, Miles J, Dew L, McCann AJ, Colbourne R, Miller
PJ, Joyce L 1996. Role of predation in the decline of kiwi, Apteryx spp., in New Zealand. New Zealand Journal of Ecology 20: 27-35.

Moorhouse RJ 1991. Annual variation in productivity of North Island kaka on Kapiti Island, New Zealand. Acta XX Congressus Internationalis Ornithologici Vol II. 690-696.

Moorhouse RJ, Greene TC, Dilks PJ, Powlesland RG, Moran L, Taylor GE, Jones A, Knegtmans JW, Wills D, Pryde M, Fraser I, August A, August C 2003. Control of introduced mammalian predators improves kaka Nestor meridionalis breeding success: Reversing the decline of a threatened New Zealand parrot. Biological Conservation 110: 33-44.

Murphy EC 1992. The effects of a natural increase in food supply on a wild population of house mice. New Zealand Journal of Ecology 16: 33-40.

Murphy EC, Dowding JE 1995. Ecology of the stoat in Nothofagus forest: Home range, habitat use and diet at different stages of the beech mast cycle. New Zealand Journal of Ecology 19: 97-109.

Murphy EC, Clapperton BK, Bradfield P, Speed H 1998. Effects of rat-poisoning operations on abundance and diet of mustelids in New Zealand forests. New Zealand Journal of Zoology 25: 315-328.

MurphyEC, Robbins L, Young JB, Dowding JE 1999. Secondary poisoning of stoats after an aerial 1080 poison operation in Pureora forest, New Zealand. New Zealand Journal of Ecology 23: 175-182.

Murphy EC, Maddigan F, Edwards B, Clapperton K 2008. Diet of stoats at Okarito Kiwi Sanctuary, South Westland, New Zealand. New Zealand Journal of Ecology 32: 41-45.

Norton D, Kelly D 1988. Mast seeding over 33 years by Dacrydium cupressimum Lamb. (rimu) (Podocarpaceae) in New Zealand: The importance of economies of scale. Functional Ecology 2: 399-408.

NPCA (National Pest Control Agencies) 2011. Possum Population Monitoring Using the Trap-Catch Method. Wellington, National Pest Control Agencies. 15 p.

Nugent G, Warburton B, Thomson C, Sweetapple P, Ruscoe WA 2011. Effect of prefeeding, sowing rate and sowing pattern on efficacy of aerial 1080 poisoning of small-mammal pests in New Zealand. Wildlife Research 38: 249-259.

O’Donnell C, Hoare J 2012. Quantifying the benefits of longterm integrated pest control for forest bird populations in a New Zealand temperate rainforest. New Zealand Journal of Ecology 36: 131-140.

O’Donnell CJF, Dilks PJ, Elliott GP 1996. Control of a stoat (Mustela erminea) population irruption to enhance mohua (yellowhead) (Mohoua ochrocephala) breeding success in NewZealand. NewZealand Journal ofZoology 23:279-286.

Powlesland RG, Wills DE, August ACL, August C 2003. Effects of a 1080 operation on kaka and kereru survival and nesting success, Whirinaki Forest Park. New Zealand Journal of Ecology 27: 125-137.

Pryde M, O’Donnell CJF, Barker RJ 2005. Factors influencing survival and long-term population viability of New Zealand long-tailed bats (Chalinolobus tuberculatus): Implications for conservation. Biological Conservation 126: 175-185.

R Core Team 2016. R:Alanguage and environment for statistical computing. R Foundation for Statistical Computing, Vienna, Austria.

Rheindt FE, Christidis L, Kuhn S, de Kloet S, Norman JA, Fidler A 2014. The timing of diversification within the most divergent parrot clade. Journal of Avian Biology 45: $140-148$. 
Robertson CJR, Hyvonen P, Fraser M., Pickard CR 2007. Atlas of bird distribution in New Zealand. Wellington, The Ornithological Society of New Zealand, Inc. 533 p.

Robertson HA, Baird K, Dowding JE, Elliott GP, Hitchmough RA, Miskelly CM, McArthur N, O’Donnell CJF, Sagar PM, Sager RP, Taylor G 2017. Conservation status of New Zealand birds, 2016. New Zealand Threat Classification Series 19. Wellington, New Zealand, Department of Conservation. $22 \mathrm{p}$.

Rotella J, Dinsmore SJ, ShafferT 2004. Modeling nest-survival data:A comparison of recently developed methods that can be implemented in MARK and SAS. Animal Biodiversity and Conservation 27: 187-205.

Ruscoe WA, Ramsey D, Pech RP, Sweetapple P, Yockney I, Barron M, Perry M, Nugent G, Carran R, Warne R, Brausch C, Duncan P 2011. Unexpected consequences of control: Competitive vs. predator release in a four-species assemblage of invasive mammals. Ecology Letters 14: 1035-1042.

Ruscoe WA, Sweetapple PJ, Perry M, Duncan RP2013. Effects of spatially extensive control of invasive rats on abundance of native invertebrates in mainland New Zealand forests. Conservation Biology 27: 74-82.

Smith DHV, Wilson DJ, Moller H, Murphy EC, van Heezik Y 2007. Selection of alpine grasslands over beech forest by stoats (Mustela erminea) in montane southern New Zealand. New Zealand Journal of Ecology 31: 88-97.

Sweetapple P 2003. Possum (Trichosurus vulpecula) diet in a mast and non-mast seed year in a New Zealand Nothofagus forest. New Zealand Journal of Ecology 27: 157-167.

Sweetapple P, Nugent G 2007. Ship rat demography and diet following possum control in a mixed podocarp-hardwood forest. New Zealand Journal of Ecology 31: 186-201.

Received 19 December 2017; accepted 26 April 2018

Editorial board member: Deb Wilson
Tompkins DM, Veltman CJ 2006. Unexpected consequences of vertebrate pest control: Predictions from a fourspecies community model. Ecological Applications 16: 1050-1061.

Veltman CJ, Westbrooke IM 2011. Forest bird mortality and baiting practices in New Zealand aerial 1080 operations from 1986 to 2009. New Zealand Journal of Ecology 35: 21-29.

Wardle J 1984. The New Zealand beeches. Ecology, utilisation and management. Wellington, New Zealand Forest Service. $447 \mathrm{p}$.

White G, Burnham KP 1999. Program MARK: Survival estimation from populations of marked animals. Bird Study 46: 120-139.

Whitehead AL, Edge K-A, Smart A, Hill G, Willans M 2008. Large scale predator control improves the productivity of a rare New Zealand riverine duck. Biological Conservation 141: 2784-2794.

Wickham H 2009. ggplot2: Elegant Graphics for DataAnalysis; Springer-Verlag New York.

Wilson DJ, Lee WG 2010. Primary and secondary resource pulses in an alpine ecosystem: Snow tussock grass (Chionochloa spp.) flowering and house mouse (Mus musculus) populations inNew Zealand. Wildlife Research 37: 89-103.

Wilson PR, Karl BJ, Toft RJ, Beggs JR, Taylor RH 1998. The role of introduced predators and competitors in the decline of kaka (Nestor meridionalis) populations in New Zealand. Biological Conservation 83: 175-185.

Yee TW 2010. The VGAM Package for Categorical Data Analysis. Journal of Statistical Software 31: 1-34. 